\title{
U-TURN LANES IN NARROW-WIDTH MEDIAN OPENINGS: DESIGN CRITERIA FOR A SAFE AND EFFICIENT PROJECT
}

\begin{abstract}
N. DISTEFANO ${ }^{1}$, S. LEONARDI ${ }^{2}$
U-turn lanes eliminate left turns at intersections and allow the manoeuvre to be made via median crossovers beyond the intersection. However, there are many situations where road infrastructures are characterized by the reduced width of the median. It is clear that, in such situations, we must adopt design criteria that take into account limitations imposed by the width of the cross-section of the road.

This is the reason why it is necessary to adopt design solutions which expect a complete reorganization of the road section affected by the insertion of U-turns.

In this paper, we intend to propose original guidelines for U-turn lane design, suitable to guarantee both the necessity to offer a high level of functionality of the road sections to be implemented by U-turns, and the principles of safety in order to reduce unsafe conditions during inversion manoeuvres as much as possible.

Keywords: safety roads, U-turn road design, intersection, median opening.
\end{abstract}

\section{INTRODUCTION}

The absence of openings in medians of road sections, does not permit drivers to turn left and therefore users often search for alternative ways to turn or make U-turn manoeuvres in road sections where it is not allowed. These factors considerably increase the risk of accidents (collisions with

\footnotetext{
${ }^{1}$ PhD., Department of Civil Engineering and Architecture, Viale A. Doria 6, Catania, 95125, Italy. e-mail: ndistefa@dica.unict.it

2 Prof., Department of Civil Engineering and Architecture, Viale A. Doria 6, Catania, 95125, Italy. e-mail: sleona@dica.unict.it
} 
other vehicles making U-turn manoeuvres or crossing in the opposite direction, rear-ended by vehicles decelerating while making U-turns and run-off the running lane done by vehicles which change direction). A design solution already widespread in many countries is represented by dedicated and delimited lanes which permit U-turns in correspondence of the median opening. The above lanes are generally identified with the designation "U-turns". The location of U-turn median openings designed for diverted left turns from side streets is determined by the weaving length between the side street and the downstream U-turn median opening. The weaving length does have an impact on the weaving patterns and total travel time for right-turn-plus-U-turn (RTUT) vehicles. If the weaving length is too long, the travel distance and travel time for diverted left turn movements will increase. If the weaving length is too short, it may cause safety and operation problems for RTUT movements crossing the through lanes and weaving to U-turn median openings.

Liu et al. [1] show that separation distance significantly impacts safety of street segments between driveways and downstream U-turn locations; a 10\% increase in separation distance will result in a $3.3 \%$ decrease in total crashes and a $4.5 \%$ decrease in crashes which are related with right-turns followed by U-turns. Zhou et al. [2] analyzes traffic operations (weaving and delay) for right turns followed by U-turn movements on urban and suburban multi-lane roadways. A working model was developed to guide U-turn median location by minimizing the average delay for U-turn movements. A case study demonstrates operations and safety improvements of optimal U-turn median design. Liu et al. [3] evaluate the operational effects of U-turns on four-lane divided roadways. The conclusions of this study are as follows: 1) the average turning speed of U-turning vehicles decreases with the increasing turning radius accommodated at a median opening and reaches a relatively stable state after the accommodated turning radius reaches around 46 to $48 \mathrm{ft} ; 2$ ) a roadway width (width of receiving lanes plus the median nose width) of $46 \mathrm{ft}$ is generally sufficient for most vehicle types (except heavy vehicles) to perform a continuous U-turn manoeuvre without impedance. If the width of receiving lanes plus the median nose width is less than $46 \mathrm{ft}$ at a median opening, extra pavements should be added through the use of a taper, a flare, or a loon to facilitate motion for vehicles making U-turns; 3) delay of U-turning vehicles at a median opening increases with the conflicting major road through traffic volume and U-turn volume. Vehicles using extra pavements to perform U-turn manoeuvres will cause a relatively longer delay than those making Uturns at wide medians.

Several researches, supported by experimental surveys on U-turn facilities, concluded that median opening zones, irrespective of their traffic conflict minimisation roles, will trigger significant travel 
speed reduction. In particular, the results of the research of Rahman et al. [4], show a significant decrease in travel speed of up to $54.2 \%$ at the diverging section of the median opening zone. A slight drop of about $5 \%$ resulted from median opening zones at the merging section. At the merging section vehicles exiting from the U-turn facilities must give way to all approaching vehicles, hence the slight speed drop at these sections.

About the design aspects, internationally, there is a fairly small number of technical standards for the design of lanes dedicated to U-turns. In particular, the study "A Policy on Geometric Design of Highways and Streets" (“Green Book") published by AASHTO and the Report 524 published by NCHRP named "Safety of U-Turns at unsignalized Median Openings" are some good guidelines. They come to design criteria based on the principle that the U-turn can be achieved by exploiting the wide median strip at the center of the roadway, including the possibility of few adaptation interventions of the cross-section of the road. However, there are many situations where road infrastructures are characterized by reduced median widths. It is clear that, in such situations, the design criteria collected from international literature cannot be applied slavishly, but should be adapted to take into account the limitations imposed by the width of the cross section of the road. This is the reason why it is necessary to adopt design solutions which expect a complete reorganization of the road section affected by the insertion of U-turns.

In this paper, we intend to elaborate guidelines for U-turn lane design, suitable to guarantee both the necessity to offer a high level of functionality of the road sections to be implemented by U-turns, and the principles of safety in order to reduce as much as possible unsafe conditions during inversion manoeuvres.

\section{DESIGN CRITERIA FOR U-TURN LANES}

Design criteria for midblock median openings for U-turn manoeuvres presented in this paper are based on two "Base-schemes" which are most indicated for the correct execution of the maneuvers of the U-turn.

In particular, the "Base - scheme $n^{\circ} 1$ " regards U-turns done by vehicles that are coming from the main road and want to enter the secondary road. The "Base - scheme $\mathrm{n}^{\circ} 2$ " regards driving direction reversals done by vehicles coming from a secondary road. In order to guarantee high safety levels during manoeuvres of entrance into ongoing traffic flow conflict or manoeuvres of lane change, which always are subject to "moments of waiting", other connecting elements should be considered in addition to the lane reversal. In order to obtain a correct and efficient organization of all U-turn 
lanes, it is essential to expect an enlargement of the carriage cross-section due to the necessity to insert U-turns and to insert additional lanes. Therefore, the median will have a minimum width in accordance with standards in the road section not affected by the future U-turn and a width of at least $20 \mathrm{~m}$ in the section where the reverse lanes have to be placed.

\subsection{BASE - SCHEME $\mathrm{N}^{\circ} 1$}

The module elements of the base scheme $n^{\circ} 1$ showed in fig. 1 , are the following ones:

Dedicated lane for U-turns;

$>$ Road section for lane changes;

Exit lane.

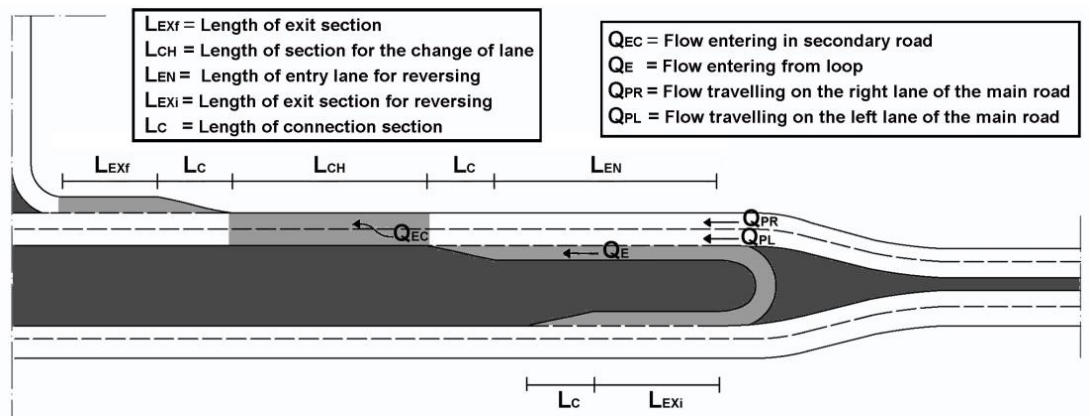

Fig. 1. Base -scheme ${ }^{\circ} 1$

\subsubsection{DEDICATED LANE FOR U-TURNS}

The lane is composed of the following elements: 1) Initial connection section, length $\mathrm{L}_{\mathrm{C}}$; 2) Exit section for reversing, length LEXi; 3) Loop; 4) Entry lane for reversing, length LeN; 5) Final connection section, length $\mathrm{L}_{\mathrm{C}}$.

The initial section represents a connection between the dedicated lane, obtained thought a crosswise enlargement of the road, and the main road. The length $\left(\mathrm{L}_{\mathrm{C}}\right)$ of this connection element has to be equal to at least $20 \mathrm{~m}$. Its geometrical construction will be done through the composition of the following three segments, each having a length equal to $\mathrm{L}_{\mathrm{C}} / 3$ (Fig. 2):

- a curvilinear section, corresponding to a deviation equal to $1 / 4$ of total displacement (d);

- a rectilinear section, corresponding to a deviation equal to $1 / 2$ of (d); 
- a curvilinear section with a curve, oriented in the direction opposite to the first one, and characterized by a deviation equal to $1 / 4$ of (d).

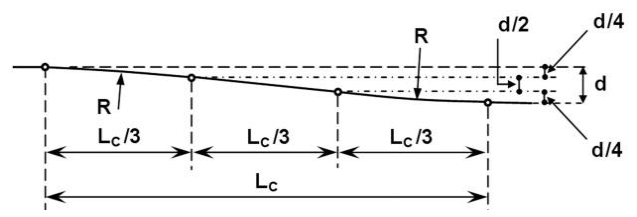

Fig. 2. Geometrical construction of the initial connection section

The radius value $(\mathrm{R})$ of the two curvilinear and symmetric sections is calculated by the following expression (lengths are expressed in meters):

$$
R=\frac{2}{9} \times \frac{L_{C}^{2}}{d}
$$

The exit section with length $\mathrm{L}_{\mathrm{EXi}}$ is necessary for allowing vehicle's diversion from the main flow to the U-turn. The table 1, from the book "Progettare le intersezioni” (Designing of Intersections, published in October 2011) [5] can be taken as reference for estimating its length. The values in Table 1 are based on exit section design as a deceleration section, with a final speed of $25 \mathrm{~km} / \mathrm{h}$

Table 1. Length of the exit section

\begin{tabular}{|l|c|c|}
\hline \multirow{4}{*}{ Urban } & Speed & LEXi \\
\hline & $40 \mathrm{~km} / \mathrm{h}$ & $10 \mathrm{~m}$ \\
\cline { 2 - 3 } & $50 \mathrm{~km} / \mathrm{h}$ & $25 \mathrm{~m}$ \\
\cline { 2 - 3 } & $60 \mathrm{~km} / \mathrm{h}$ & $50 \mathrm{~m}$ \\
\hline \multirow{5}{*}{ Rural } & $40 \mathrm{~km} / \mathrm{h}$ & $5 \mathrm{~m}$ \\
\cline { 2 - 3 } & $50 \mathrm{~km} / \mathrm{h}$ & $15 \mathrm{~m}$ \\
\cline { 2 - 3 } & $60 \mathrm{~km} / \mathrm{h}$ & $45 \mathrm{~m}$ \\
\cline { 2 - 3 } & $70 \mathrm{~km} / \mathrm{h}$ & $65 \mathrm{~m}$ \\
\cline { 2 - 3 } & $80 \mathrm{~km} / \mathrm{h}$ & $95 \mathrm{~m}$ \\
\cline { 2 - 3 } & $90 \mathrm{~km} / \mathrm{h}$ & $130 \mathrm{~m}$ \\
\cline { 2 - 3 } & $100 \mathrm{~km} / \mathrm{h}$ & $165 \mathrm{~m}$ \\
\hline
\end{tabular}

The first step for designing a loop for U-Turn manoeuvre is to define the inner edge of the expected U-turn. The shape of this curve is defined by an approximation, similar to the curb curve for the 
right turn in correspondence of grade intersections, of the internal trajectory of heavy vehicles, which transit on small radius curves and a large angle of deviation.

In this specific case the utilization of three centered asymmetric compound curve is expected. These curves are composed of three arches which have the same tangents at the connection points, but each one has different radius and angle. These curves must observe the following geometrical standards, both for the angles and the radius:

- $\alpha_{1}+\alpha_{2}+\alpha_{3}=180^{\circ} \quad ; \quad \alpha_{1}=\alpha_{3} \quad ; \quad \alpha_{2}=5,5 \cdot \alpha_{1}$

- $\mathrm{R}_{1}: \mathrm{R}_{2}: \mathrm{R}_{3}=2,5: 1: 2,5$

It can be noted that the last analytic condition represents an undetermined system of equation; it is necessary to set up the value of one of the three variables for its solution. It is recommended to fix the radius of the central arch of the three curves $\left(\mathrm{R}_{2}\right)$ as it defines the real turning modalities.

For the overall design characterization of the U-turn/loop it is necessary to expect the set out of the area engaged in a dynamic way by turning vehicles. This area is individuated by transversal displacements compared to the curves of the edge. Fig. 3 shows the symbology used for identifying the segments which represent the displacements compared to the edge and which are necessary for the set out of the strip. All design parameters, associated with the three values of the central radius of the loop, which are most significant in the configuration of design activities, are shown in Table 2. The values of the displacements $\Delta_{\mathrm{i}}$, were obtained from a study about trajectories performed by different vehicles (cars, trucks and buses). This study was done using the simulation software Autoturn ${ }^{\circledR} 6.0$ of the Civil Engineering Department of the University of Catania.

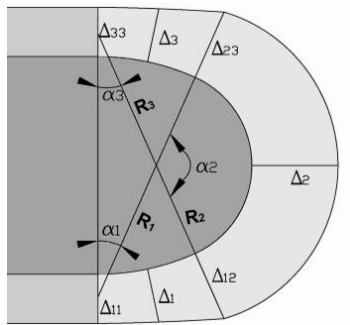

Fig. 3. Geometrical elements for a loop design 
Table 2. Example values of design parameters regarding loops for U-turns

\begin{tabular}{|c|c|c|c|c|c|c|c|c|c|c|c|c|}
\hline \multicolumn{4}{|c|}{ Angles } & \multicolumn{10}{|c|}{ Radius and minimal displacements } \\
\hline$\alpha_{1}$ & $\alpha_{2}$ & $\alpha_{3}$ & $\mathrm{R}_{1}(\mathrm{~m})$ & $\mathrm{R}_{2}(\mathrm{~m})$ & $\mathrm{R}_{3}(\mathrm{~m})$ & $\Delta_{11}(\mathrm{~m})$ & $\Delta_{1}(\mathrm{~m})$ & $\Delta_{12}(\mathrm{~m})$ & $\Delta_{2}(\mathrm{~m})$ & $\Delta_{23}(\mathrm{~m})$ & $\Delta_{3}(\mathrm{~m})$ & $\Delta_{33}(\mathrm{~m})$ \\
\hline $24^{\circ}$ & $132^{\circ}$ & $24^{\circ}$ & 20,0 & 8 & 20,0 & 3,50 & 3,85 & 5,10 & 6,95 & 5,10 & 3,85 & 3,50 \\
\hline $24^{\circ}$ & $132^{\circ}$ & $24^{\circ}$ & 22,5 & 9 & 22,5 & 3,50 & 3,75 & 5,00 & 6,80 & 5,00 & 3,75 & 3,50 \\
\hline $24^{\circ}$ & $132^{\circ}$ & $24^{\circ}$ & 25,0 & 10 & 25,0 & 3,50 & 3,70 & 4,90 & 6,70 & 4,90 & 3,70 & 3,50 \\
\hline
\end{tabular}

The entry section is the design element used by vehicles coming from the loop and entering into the left lane of the main road. By using the right side rearview mirror the user who is traveling the road values the space available for getting into the internal part of the main road between two consecutive vehicles without creating decelerations and without constraining other arriving users to change lanes. Therefore, the entry section is an awaiting section which allows the user to increase slowly the speed and then to capture the most opportune moment for getting into the main vehicles' flow. This described type of entry is the "perfect entry", while the short time interval between two vehicles traveling in the main traffic flow is called the "critical gap" (T).

In order to evaluate the critical gap, a simplified model (widely used in literature) was employed, based on the following main hypotheses: 1) the vehicles present on the main road are traveling at a constant speed; 2) the vehicles incoming from the loop start to move in a uniformly accelerated motion; 3) the safety distance between vehicles is constant.

The analytical expression to quantify the critical interval is the following one:

$$
T=\frac{S_{P L}-S_{E}}{2 a_{c}}+2 \times \delta
$$

$\mathrm{S}_{\mathrm{E}}=$ speed of the traffic flow incoming from the loop $\left(\mathrm{Q}_{\mathrm{E}}\right)$, measured in $\mathrm{m} / \mathrm{s}$;

$\mathrm{SPL}_{\mathrm{L}}=$ speed of the traffic flow in conflict with the flow $\mathrm{Q}_{\mathrm{E}}$, traveling in the left lane of the main road $\left(\mathrm{Q}_{\mathrm{PL}}\right)$;

$\delta=$ temporal safety distance between two consecutive vehicles on the main road. Generally, it is fixed at 1s;

$a_{\mathrm{c}}=$ longitudinal average acceleration. It is fixed at $1,2 \mathrm{~m} / \mathrm{s}^{2} ;$.

Ultimately, a vehicle traveling in the entry section (awaiting section) will enter into the left lane of the main road when there is a temporal interval at least equal to the value of $\mathrm{T}$.

The presence of the critical interval $(\mathrm{T})$ in each case is a random event. Therefore, it is possible to presume that the temporal interval $\square$ whereby vehicles follow one other in the left lane of the main road ahead the vehicle coming from the U-turn, observes the law of Poisson distribution.

In this case, the length of the entry section $\mathrm{L}_{\mathrm{EN}}$ will be determined, using the following expression: 


$$
L_{E N}=(k-1) \times \lambda^{-1} \times S_{E}
$$

$\mathrm{k}=$ the number of events (occurrences of vehicles traveling in the left lane of the main road) corresponding to the value of the design probability;

$1 / \lambda=$ temporal duration of each single event (s);

$\mathrm{S}_{\mathrm{E}}=$ traffic flow speed at the entrance of the loop $\left(\mathrm{Q}_{\mathrm{E}}\right)$, expressed in $\mathrm{m} / \mathrm{s}$.

In the present study, the writers set out in Tables 3, 4, and 5, the values of the length of the awaiting section for three different design probabilities $(90 \%, 80 \%$ e $70 \%)$, depending on the volume of traffic flow which conflict with those who are waiting for the perfect entry.

Three reference values of the effective speed of traffic flow were used $(70 \mathrm{~km} / \mathrm{h}, 60 \mathrm{~km} / \mathrm{h}, 50 \mathrm{~km} / \mathrm{h})$.

The reference speeds are the following: a) the design speed for new designs; b) the operating speed (e.g. $\mathrm{S}_{85}$ ) for existing roads. The vehicle flows are expressed in terms of equivalent vehicles.

Table 3. Values of the length of the awaiting section (Design probabilities $=90 \%$ )

\begin{tabular}{|c|c|c|c|c|c|c|c|c|c|}
\hline & \multicolumn{9}{|c|}{ Speed of the conflicting flow rate } \\
\hline & \multicolumn{3}{|c|}{$70 \mathrm{~km} / \mathrm{h}$} & \multicolumn{3}{|c|}{$60 \mathrm{~km} / \mathrm{h}$} & \multicolumn{3}{|c|}{$50 \mathrm{~km} / \mathrm{h}$} \\
\hline & \multicolumn{3}{|c|}{$\begin{array}{c}\text { Speed of the flow rate in } \\
\text { manoeuvre }\end{array}$} & \multicolumn{3}{|c|}{$\begin{array}{c}\text { Speed of the flow rate in } \\
\text { manoeuvre }\end{array}$} & \multicolumn{3}{|c|}{$\begin{array}{c}\text { Speed of the flow rate in } \\
\text { manoeuvre }\end{array}$} \\
\hline & $50 \mathrm{~km} / \mathrm{h}$ & $60 \mathrm{~km} / \mathrm{h}$ & $70 \mathrm{~km} / \mathrm{h}$ & $40 \mathrm{~km} / \mathrm{h}$ & $50 \mathrm{~km} / \mathrm{h}$ & $60 \mathrm{~km} / \mathrm{h}$ & $30 \mathrm{~km} / \mathrm{h}$ & $40 \mathrm{~km} / \mathrm{h}$ & $50 \mathrm{~km} / \mathrm{h}$ \\
\hline $\begin{array}{l}\text { Conflicting flow rate } \\
\text { (v/h) }\end{array}$ & \multicolumn{9}{|c|}{ LENGHT OF THE AWAITING SECTION (m) - Design probability = 90\% } \\
\hline 2000 & 600 & 340 & 170 & 400 & 290 & 150 & 350 & 225 & 120 \\
\hline 1800 & 500 & 300 & 165 & 350 & 250 & 135 & 290 & 200 & 115 \\
\hline 1600 & 410 & 275 & 155 & 325 & 225 & 130 & 245 & 185 & 110 \\
\hline 1400 & 365 & 250 & 150 & 300 & 205 & 125 & 225 & 165 & 100 \\
\hline 1200 & 315 & 225 & 145 & 250 & 190 & 110 & 190 & 150 & 90 \\
\hline 1000 & 275 & 205 & 135 & 220 & 175 & 110 & 165 & 135 & 90 \\
\hline 800 & 240 & 190 & 130 & 190 & 155 & 100 & 140 & 125 & 80 \\
\hline 600 & 225 & 180 & 115 & 170 & 145 & 90 & 130 & 120 & 70 \\
\hline 500 & 190 & 160 & 115 & 155 & 130 & 80 & 120 & 110 & 70 \\
\hline 400 & 185 & 135 & 105 & 150 & 125 & 70 & 115 & 90 & 60 \\
\hline 200 & 185 & 120 & 70 & 140 & 120 & 50 & 95 & 70 & 40 \\
\hline 100 & 175 & 60 & 35 & 80 & 50 & 25 & 30 & 30 & 20 \\
\hline
\end{tabular}


Table 4 . Values of the length of the awaiting section (Design probabilities $=80 \%$ )

\begin{tabular}{|c|c|c|c|c|c|c|c|c|c|}
\hline & \multicolumn{9}{|c|}{ Speed of the conflicting flow rate } \\
\hline & \multirow{2}{*}{\multicolumn{3}{|c|}{$\begin{array}{c}\mathbf{7 0} \mathbf{~ k m} / \mathbf{h} \\
\begin{array}{c}\text { Speed of the flow rate in } \\
\text { manoeuvre }\end{array}\end{array}$}} & \multirow{2}{*}{\multicolumn{3}{|c|}{$\begin{array}{c}\mathbf{6 0} \mathbf{~ k m} / \mathbf{h} \\
\begin{array}{c}\text { Speed of the flow rate in } \\
\text { manoeuvre }\end{array}\end{array}$}} & \multirow{2}{*}{\multicolumn{3}{|c|}{$\begin{array}{c}\mathbf{5 0} \mathbf{~ k m} / \mathbf{h} \\
\begin{array}{l}\text { Speed of the flow rate in } \\
\text { manoeuvre }\end{array}\end{array}$}} \\
\hline & & & & & & & & & \\
\hline & $50 \mathrm{~km} / \mathrm{h}$ & $60 \mathrm{~km} / \mathrm{h}$ & $70 \mathrm{~km} / \mathrm{h}$ & $40 \mathrm{~km} / \mathrm{h}$ & $50 \mathrm{~km} / \mathrm{h}$ & $60 \mathrm{~km} / \mathrm{h}$ & $30 \mathrm{~km} / \mathrm{h}$ & $40 \mathrm{~km} / \mathrm{h}$ & $50 \mathrm{~km} / \mathrm{h}$ \\
\hline $\begin{array}{c}\text { Conflicting flow rate } \\
(\mathrm{v} / \mathrm{h})\end{array}$ & \multicolumn{9}{|c|}{ LENGHT OF THE AWAITING SECTION (m) - Design probability $=80 \%$} \\
\hline 2000 & 450 & 225 & 105 & 325 & 190 & 90 & 255 & 150 & 80 \\
\hline 1800 & 350 & 200 & 95 & 270 & 165 & 85 & 200 & 135 & 70 \\
\hline 1600 & 285 & 180 & 90 & 225 & 150 & 75 & 170 & 120 & 65 \\
\hline 1400 & 245 & 155 & 90 & 195 & 135 & 75 & 145 & 110 & 60 \\
\hline 1200 & 205 & 135 & 80 & 165 & 120 & 70 & 125 & 95 & 60 \\
\hline 1000 & 180 & 115 & 60 & 145 & 100 & 60 & 110 & 80 & 50 \\
\hline 800 & 155 & 115 & 55 & 125 & 90 & 60 & 90 & 75 & 50 \\
\hline 600 & 120 & 100 & 55 & 100 & 85 & 60 & 75 & 65 & 50 \\
\hline 500 & 110 & 100 & 45 & 95 & 75 & 50 & 60 & 65 & 40 \\
\hline 400 & 100 & 75 & 20 & 80 & 65 & 30 & 55 & 50 & 30 \\
\hline 200 & 25 & 35 & 10 & 30 & 15 & 10 & 20 & 10 & - \\
\hline 100 & 10 & 10 & - & 10 & 10 & - & - & - & - \\
\hline
\end{tabular}

Table 5. Values of the length of the awaiting section (Design probabilities $=70 \%$ )

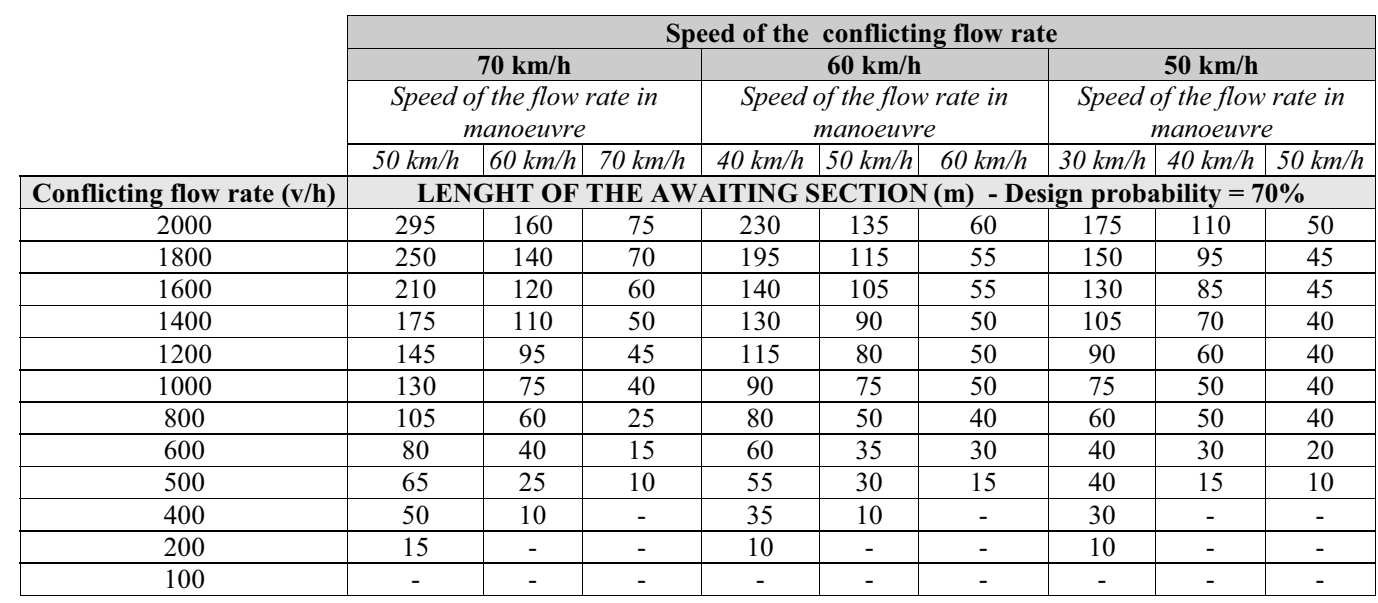

The designer has to choose the percentile of waiting time (design probability) and this choice will determine the length of the awaiting section. It is recommended to choose an elevated percentile, normally the ninetieth. However, it is necessary to not rule out the possibility, in case of specific situations (due to spatial constraints), to use the awaiting section lengths related to percentiles of minor waiting time. Nonetheless, it is not advisable to drop below the threshold of $70 \%$ of the probability of a time gap equal to or longer than the critical interval. 
Just like the initial section, the final section is essential for connecting the special lane for reversals and the left lane of the main road. The length $\left(\mathrm{L}_{\mathrm{C}}\right)$ of this section and the standards of its placement are the same as those of the initial section.

\subsubsection{SECTION FOR THE CHANGE OF LANE}

This section is travelled by vehicles coming from the U-turn lane and attempting entry into the secondary road before getting into the right lane of the main road; in this case the user must assess the available space-time in the traffic flow in the right lane of the main road.

The length $\mathrm{L}_{\mathrm{CH}}$ will be evaluated accordingly to the criteria of the awaiting sections already described. It is necessary to select one of the design tables (Table 3, Table 4, Table 5), in accordance to a chosen percentile of waiting time. The determination of the value of $\mathrm{L}_{\mathrm{CH}}$ will be determined after the input of the following data: the speed of traffic flow coming from the U-turn which is going to enter the secondary road $\left(\mathrm{Q}_{\mathrm{EC}}\right)$ and the speed and the flow associated with the vehicular flow in conflict in the right lane of the main road (QPR). The traffic flow traveling in the left lane which is turning to the right towards the secondary road is considered null (or at least insignificant).

\subsubsection{EXIT LANE}

The exit lane is composed of a connection section $\left(\mathrm{L}_{\mathrm{C}}\right)$ and an exit section $\left(\mathrm{L}_{\mathrm{EXf}}\right)$. The geometric construction of the connection section will have the same above-mentioned standards used also for the construction of the initial and final section of the road and for the special lane for U-turns. The exit section allows for the diversion of vehicles coming from the main road traveling to the secondary road. For estimating the length (LEXf) of the exit section Table 1 can be used as in the case of the exit section for inversions.

\subsection{BASE - SCHEME $\mathrm{N}^{\circ} 2$}

The module composition of the base - scheme $n^{\circ} 2$ needs the following elements (Fig. 4):

$>$ Entry lane;

$>$ Road section for lane changes;

$>$ Dedicated lane for U-turns. 


\subsubsection{ENTRY LANE}

The entry lane is composed of an awaiting section $\left(\mathrm{L}_{\mathrm{ENi}}\right)$ and a connection section $\left(\mathrm{L}_{\mathrm{C}}\right)$. The awaiting section is used for entering the main road coming from the secondary leg. The drivers of the incoming vehicles that use the left rear-view mirror consider the space-time interval between the vehicles on the main road, and then they will be able to enter the main street. Its length $\mathrm{LENi}_{\mathrm{EN}}$ can be determined by the use of one of the above mentioned tables (Table 3, Table 4 and Table 5), depending on the selected percentile of waiting time $(90 \%, 80 \%$ or $70 \%)$. The input data consists of the velocity of the traffic flow incoming from the secondary road (QES) and of the speed values and flow related to the traffic in conflict in the right lane of the main road ( $\left.Q_{P R 1}\right)$. The design of the connection section will proceed as for sections with similar functionalities, described in the treatment concerning the base-scheme $\mathrm{n}^{\circ} 1$.

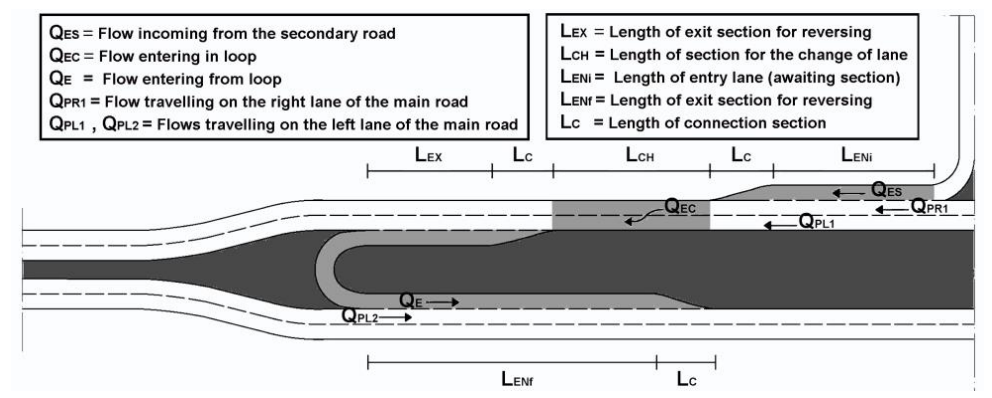

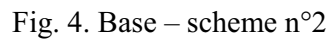

\subsubsection{ROAD SECTION FOR LANE CHANGES}

This design element with length $\mathrm{L}_{\mathrm{CH}}$ is the section used by vehicles which, before getting into the loop to make a U-turn, have to move laterally to the left side of the main road. In this case the drivers have to wait for the opportune space-time interval in order to do the maneuver safely.

The calculation of its length can be determined similarly at the section for the change of lane of paragraph 2.1.2.

\subsubsection{DEDICATED U-TURN LANE}

It is composed of the following elements: 1) Initial connection section, length $\mathrm{L}_{\mathrm{C}}$; 2) Exit section for reversing, length LEx; 3) Loop; 4) Entry lane for reversing, length LENf; 5) Final connection section, length $\mathrm{L}_{\mathrm{C}}$. 
The initial section with length $\mathrm{L}_{\mathrm{C}}$ is essential for connecting the left lane of the main road to the subsequent exit section for reversing; its length has to be equal to at least $20 \mathrm{~m}$ and its geometrical construction will be calculated following the same standards of sections with similar functions, as previously described. The exit section is used by vehicles that want to enter the subsequent loop for leaving the internal lane of the main road; in this way they interfere the least with the vehicles traveling straight ahead in the left lane of the main road. For evaluating its length ( $\left.\mathrm{L}_{\mathrm{EX}}\right)$, the values of Table 1 can be used as reference. Regarding the design of the loop it is necessary to refer to the criteria illustrated in the paragraph relating to the base-scheme No. 1, for the dimensioning of the geometrical element with similar features and functionality. The entry lane for reversing is the design element used by vehicles coming from the loop for getting into the left lane of the road; therefore, the driver in the entry section has to estimate the interval available for getting between two consecutive vehicles traveling on the main road, by using the right side rear-view mirror. As in the previous case, it is necessary to consult one of the already mentioned tables (Table 3, Table 4, Table 5), depending on the most opportune waiting time percentile. The input data necessary for evaluating $\mathrm{L}_{\mathrm{ENf}}$ are: the speed of the flow entering the loop $\left(\mathrm{Q}_{\mathrm{E}}\right)$ and the values of velocity and vehicle flow associated with the traffic flow in conflict in the left lane of the main road (QPL2). The final section, as the initial one, connects the special lane for U-turns to the left lane of the main road. Its length $\left(\mathrm{LC}_{\mathrm{C}}\right)$ and placement standards are the same as previously described for other geometrical elements with transition functions.

\section{Conclusions}

The need to reverse the driving direction along a separated carriageway road is often due to the presence of central medians which impede the access on the left to minor roads. The U-turn lanes represent a design solution guaranteeing users a safe and quick entrance into secondary roads. In this paper, we have developed rational criteria for the design of all elements of the above lanes: entry and exit lanes, connection sections, road sections for lane changes, loops obtained by median openings. It is believed that these criteria can guarantee an appropriate level of functionality and high safety standards both for users making reversing maneuvers as well as for drivers traveling on the main road which are in conflict with the traffic flows coming from or entering the loops. 


\section{REFERENCES}

1. P. Liu, J. Lu, H. Chen, G. Sokolow, "Impacts of Separation Distance between Driveway Exist and Downstream U-turn Locations on the Safety Performance of Right-turns Followed by U-turns." TRB 87th Annual Meeting Compendium of Papers CD-ROM. Washington, D.C., 2008.

2. H. Zhou, P. Hsu, J. J. Lu, J. E. Wright, "Optimal Location of U-turn Median Openings on Roadways", Transportation Research Record 1847, Journal of the Transportation Research Board, pp. 36-41, 2003.

3. P. Liu, J. Lu, H. Chen, "Safety effects of the separation distances between driveway exits and downstream Uturn locations." Accident Analysis and Prevention, Vol. 40, Issue 2, 2008.

4. R. Rahman, J. Ben-Edigbe, "Impact of Multilane Median Openings Zone on Travel Speed". Jurnal Teknologi, Vol. 73, Number 4, 15-20, 2015.

5. S. Canale, N. Distefano, S. Leonardi, G. Pappalardo, "Progettare le intersezioni - Tecniche per la progettazione e la verifica delle intersezioni stradali in ambito urbano ed extraurbano secondo il D.M. 19/04/2006". II edizione . EPC Editore, 2011.

Received 15.03.2016

Revised 19.05.2016

\section{LIST OF FIGURES AND TABLES}

Fig. 1. Base - scheme ${ }^{\circ} 1$

Rys. 1. Podstawa - schemat nr 1

Fig. 2. Geometrical construction of the initial connection section

Rys. 2. Geometryczna budowa odcinka połączenia początkowego

Fig. 3. Geometrical elements for a loop design

Rys. 3. Geometryczne elementy konstrukcji pętli

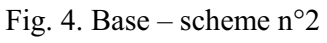

Rys. 4. Podstawa - schemat nr 2

Fig. 5. Example of U-Turn lanes between two near three leg intersections

Rys. 5. Przykład pasów do zawracania pomiędzy dwoma bliskimi skrzyżowaniami trójramiennymi

Fig. 6. Example of U-Turn lanes between two distant three leg intersections

Rys. 6. Przykład pasów do zawracania pomiędzy dwoma dalekimi skrzyżowaniami trójramiennymi

Tab. 1. Length of the exit section

Tab. 1. Długość odcinka wylotowego

Tab. 2. Example values of design parameters regarding loops for U-Turns

Tab. 2. Przykładowe wartości parametrów konstrukcyjnych dotyczących pętli do zawracania

Tab. 3. Values of the length of awaiting section (Design probabilities $=90 \%$ )

Tab. 3. Wartości długości pasa oczekiwania (Prawdopodobieństwa konstrukcyjne $=90 \%$ )

Tab. 4. Values of the length of awaiting section (Design probabilities $=80 \%$ )

Tab. 4. Wartości długości pasa oczekiwania (Prawdopodobieństwa konstrukcyjne $=80 \%$ )

Tab. 5. Values of the length of awaiting section (Design probabilities $=70 \%$ )

Tab. 5. Wartości długości pasa oczekiwania (Prawdopodobieństwa konstrukcyjne $=70 \%$ ) 


\section{PASY DO ZAWRACANIA W WĄSKIM ŚWIETLE PASA RODZELCZEGO: KRYTERIA KONSTRUKCYJNE W ZAKRESIE BEZPIECZEŃSTWA I EFEKTYWNEGO PROJEKTU}

Slowa kluczowe: drogi bezpieczeństwa, zawracanie, budowa dróg, skrzyżowanie, światło pasa rozdzielczego.

\section{STRESZCZENIE:}

Pas do zawracania eliminuje lewoskręty na skrzyżowaniach i pozwala na manewry przez punkty przecięcia pasa rozdzielczego za skrzyżowaniem. Jednak istnieje wiele sytuacji, w których infrastruktury drogowe charakteryzują się zmniejszoną szerokością pasa rozdzielczego. Jest oczywiste, że w takich sytuacjach musimy przyjąć kryteria konstrukcyjne, które biorą pod uwagę ograniczenia wynikające z szerokości przekroju drogi.

W odniesieniu do aspektów konstrukcyjnych, na całym świecie jest stosunkowo niewiele norm technicznych dotyczących projektowania pasów przeznaczonych do zawracania. Ich podejście przewiduje kryteria projektowe oparte na zasadzie, że można osiągnąć zawracanie poprzez wykorzystanie szerokiego pasa rozdzielczego w środku jezdni, w tym niewiele możliwości interwencji adaptacyjnych przekroju drogi. Niemniej jednak jest wiele sytuacji, w których infrastruktury drogowe charakteryzują się zmniejszoną szerokością pasa rozdzielczego. Jest oczywiste, że w takich sytuacjach nie można przyjąć niewolniczo kryteriów konstrukcyjnych w literaturze międzynarodowej, ale należy je przystosować biorąc pod uwagę ograniczenia wynikające z szerokości przekroju drogi.

Dlatego należy przyjąć rozwiązania projektowe, po których można oczekiwać kompletnej reorganizacji odcinka drogi, którego dotyczy umieszczenie punktów zawracania. Niniejszy artykuł proponuje autorskie wytyczne dotyczące projektowania pasów do zawracania, odpowiednie do zagwarantowania zarówno konieczności zaoferowania wysokiego poziomu funkcjonalności odcinków dróg, na których pasy do zawracania mają zostać wdrożone, jak i zasad bezpieczeństwa w celu jak największego zmniejszenia niebezpiecznych warunków w czasie wykonywania manewrów zawracania.

Kryteria konstrukcyjne dla świateł pasów rozdzielczych między skrzyżowaniami dla manewrów zawracania przedstawione w niniejszym artykule są oparte na dwóch „Podstawach-schematach”, które bardziej niż inne wskazują na prawidłowe przeprowadzanie manewrów zawracania.

W szczególności „Podstawa - schemat nr 1” w odniesieniu do manewrów zawracania wykonywanych przez pojazdy nadjeżdżające z głównej drogi i chce dostać się na drogę drugorzędną. „Podstawa - schemat nr 2” opisuje odwrócenia kierunku jazdy wykonane przez pojazdy nadjeżdżające z drogi drugorzędnej. 